\title{
PEMBENTUKAN IDENTITAS DIRI PADA KOMUNITAS LIGHT GALAXY DI SEMARANG
}

\author{
Ara Lalitya dan Heni Indrayani \\ Universitas Dian Nuswantoro \\ Email: aralalityap@gmail.com
}

\begin{abstract}
Abstrak
Saat ini, Korean Wave atau Hallyu telah menjadi salah satu minat populer di Indonesia, banyak remaja Indonesia yang secara dinamis mendistribusikan bentuk budaya pop seperti komunitas kpop dan kpop. Komunitas dance cover Light Galaxy merupakan salah satu komunitas populer di Semarang. Di komunitas ini ada banyak kegiatan yang dapat mengubah perilaku dan menjadi alasan seseorang untuk membangun identitas mereka. Itu semua karena beberapa remaja sedang dalam pencarian untuk menemukan identitas diri mereka. Oleh karena itu, penelitian ini bertujuan untuk mengetahui proses pembentukan identitas diri yang terjadi pada anggota komunitas Light Galaxy. Penelitian ini menggunakan teori simbolis interaksionisme dari George Hebert Mead. Dalam teori ini ada proses Self yang terbagi menjadi dua aspek yaitu "I" dan "Me". Pendekatan penelitian adalah kualitatif dengan menggunakan metode fenomenologi. Subjek dalam penelitian ini adalah enam anggota komunitas Light Galaxy. Untuk mengumpulkan data penelitian ini menggunakan teknik wawancara mendalam. Hasil dari penelitian ini menunjukan bahwa setiap narasumber mengalami pembentukan identitas diri ketika menjadi bagian komunitas. Pembentukan identitas terjadi karena adanya pengaruh hingga peniruan kelompok yang dilakukan oleh narasumber. Orang yang diwawancarai menjelaskan tentang pembentukan yang terjadi pada mereka selama proses berlangsung. Itu dimulai dari membentuk mind, self, dan society mereka. Selain itu, pembentukan identitas anggota membuat mereka lebih percaya diri, fashionable, dan terbuka.
\end{abstract}

Kata kunci : identitas,hallyu,remaja

\begin{abstract}
Nowdays, Korean Wave or Hallyu has become one of popular interest in Indonesia, many of Indonesian teenager dynamically distributed form of pop culture such as kpop and kpop community. Light Galaxy cover dance community is one of the popular interest group in Semarang. In this community there a lot activity that can change behavior and become a reason for someone to build their identity. That all because some teenagers are on their way to find their own self identity. Therefore, this study aims to determine the process of formationing self-identity that happened in the Light Galaxy community membersThis study uses the theory of George Hebert Mead symbolic of interactionism. In this theory there is a Self process which is divided into two aspects namely "I" and "Me". The research approach is qualitative by using phenomenology methods. The subjects in this study are six members of the Light Galaxy community.In order to collecting data this study is using in-dept interview technique. The results of this study indicate that each interviewees who are members of the Light Galaxy community revealed that they were formation when they joined the community.The formation that happen because of the impression and group imitation that carried out by the interviewees. The interviewee are describe about the formation that happen to them during the process. It is start form their mind, self, and society. In addition, the identity formation the members make them more confident, fashionable, and overt.
\end{abstract}

Keyword: hallyu,community, identity 


\section{Pendahuluan}

Masa remaja atau dapat diistilahkan sebagai masa adolescene merupakan masa periode transisi perkembangan dimulai dari masa anak-anak menuju ke masa dewasa, yang melibatkan perubahan-perubahan dalam dirinya. Keadaan ini terjadi karena di masa remaja, mereka ingin dianggap sudah bukan anak-anak lagi, tetapi di sisi lain para remaja masih dalam pengawasan dan masih bergantung pada orang tua. Hal ini lah yang menyebabkan remaja mengalami kritis identitas diri (Santrock,2003:26). Kritis identitas diri yang dimaksud merupakan selama masa perkembangan yang dialami oleh remaja, mereka akan melakukan pencarian identitas diri, dan selama pencarian identitas ini lah remaja mudah untuk dipengaruhi. Hal ini didukung pernyataan dari Fransiska Kaligis, SpKJ, Division of Child and Adolescent Psychiatry Rumah Sakit Cipto Mangunkusumo, yang menyatakan bahwa "Oleh karenanya remaja lebih mudah terpengaruh dampak buruk lingkungan, seperti kekerasan, penggunaan narkoba atau seks bebas. Remaja juga mengalami krisis identitas, dibilang dewasa belum, anak-anak juga tidak" (https://www.beritasatu.com/gaya-hidup/173183/alasan-remaja-rentan-terpengaruh-damp ak-buruk-lingkungan, diakses pada tanggal 7 Mei 2019).

Krisis identitas yang dipengaruhi lingkungan ini dapat dialami oleh remaja yang tergabung di dalam komunitas atau kelompok. Yang dimana komunitas dapat memberikan pengaruh sehingga mengubah perilaku dan membentuk identitas diri pada anggota komunitas nya. Perilaku yang berubah oleh anggota komunitas ini dikarenakan adanya pengaruh dari komunitas, hal ini diungkap oleh pakar dari Zimbardo,Profesor Psikologi di Stanford University, mengungkapkan bahwa perilaku seseorang bukan disebabkan oleh "pembawaan" mereka, namun karena adanya pengaruh kelompok yang mengubah anggota-anggotanya (Rakhmat, 2011:138). Meskipun komunitas dapat mempengaruhi remaja hingga membentuk identitas diri mereka, namun tetap saja remaja bergabung dengan komunitas karena ketika mereka menjadi bagian di dalam sebuah komunitas mereka akan merasakan lingkungan yang bersosialisasi dan kebersamaan. Seperti yang dijelaskan oleh Santrock (2003:231) bahwa remaja bergabung dengan suatu kelompok dikarenakan mereka beranggapan keanggotaan suatu kelompok akan sangat menyenangkan dan menarik dan memenuhi kebutuhan mereka atas hubungan dekat dan kebersamaan. Selain itu mereka bergabung dengan kelompok karena mereka mememiliki kesempatan untuk menerima penghargaan, baik yang berupa materi maupun psikologi.

Berbicara mengenai kelompok, terdapat beberapa komunitas atau kelompok yang berkembang di Indonesia. Salah satunya yaitu komunitas K-Pop. Komunitas K-Pop terbentuk karena adanya fenomena Hallyu yang terjadi di Indonesia. Korean Wave atau biasa diartikan dengan fenomena Hallyu dalam Wahyudi (2013:201-212) menyatakan bahwa Korean Wave merupakan salah satu peristiwa yang terjadi di jaman sekarang ini, khususnya para remaja yang jika mendengar kata "Korea" bukan menjadi hal yang asing di Indonesia, karena sebagian remaja-remaja di Indonesia saat ini sangat menyukai hal yang berbau Korea. Remaja yang 
menyukai atau fanatic dengan hal yang berbau Korea biasa disebut dengan K-Popers. K-Pop sendiri merupakan budaya berasal dari Korea Selatan yang masuk di dalam bidang entertainment khususnya musik, karena Korea sendiri memiliki genre musik pop sehingga sering disebut dengan K-Pop. Perkembangan pesat musik K-Pop yang dimana banyak didominasi oleh anak-anak muda sehingga membuat tumbuhnya kelompok atau komunitas karena memiliki hobi dan minat yang sama tentang K-Pop sehingga memutuskan membentuk sebuah kelompok atau komunitas. Komunitas atau kelompok yang terbentuk dari fenomena Hallyu salah satunya adalah cover dance, yang merupakan bentuk ekspresi penggemar k-pop di bidang dance dengan menyerupai idol-nya. Dikutip dari Korea Tourism Organization yang menjelaskan bahwa saat melalukan kegiatan cover dance memiliki fokus tersendiri yaitu mengikuti gerakan yang dilakukan oleh idol nya. Poin untuk kesempurnaannya bukan dalam bentuk kreativitas di gerakan, namun harus memiliki kemiripan dengan idola baik dalam segi detail gerakan, kostum, postur tubuh, serta ekspresi yang ditampilkan pada saat diatas panggung (http://english.visitkoreayear.com/community/community_01_01_01_view. asp?bidx=292\&st=\&sech=\&page=1, diakses pada tanggal 3 Maret 2019 ).

Komunitas K-Pop dance cover ini tentunya juga diminati oleh para remaja di Indonesia. Dikutip dari tribunjabar.com mengungkapkan bahwa kota Bandung dan Yogyakarta termasuk kota yang menjadi salah satu perkembangan cover dance di Indonesia (http://jabar.tribunnews. com/2012/03/03/cover-dance-hanguk-di-bandu ng, diakses pada tanggal 3 Maret 2019). Tidak menutup kemungkinan bahwa Semarang juga memiliki minat yang besar terhadap cover dance K-Pop. Terbukti dengan banyaknya penggemar K-Pop atau komunitas dance cover K-Pop yang mengikuti acara flashmob penggalangan untuk gempa Palu yang di publikasi lewat instagram @Hallyufestsmg. Salah satu komunitas yang sudah lama terjun dalam dunia dance cover K-Pop di Semarang adalah Light Galaxy, yang mana komunitas ini sudah berjalan selama 8 tahun sehingga memiliki 6 grup di dalamnya. Masing-masing grup tersebut memiliki ciri-ciri sesuai dengan idol grup kpop yang mereka cover, dan tentunya komunitas ini memberikan pengaruhpengaruh pada anggotanya. Di dalam komunitas ini tentunya terdapat kegiatan-kegiatan yang dimana kegiatan ini timbul simbolis interaksionisme dalam komunikasi kelompok. Menurut Hebert Blummer interkasionisme simbolik adalah suatu aktivitas yang merupakan ciri khas manusia, yakni komunikasi atau pertukaran symbol yang diberi makna (2009:149). Sehingga di dalam komunitas pastinya melakukan pertukaran symbol dan mampu memberikan makna yang sama dan menjadi satu dalam kelompok. Melalui hal ini anggota di dalam komunitas akan berusaha menjadi satu dengan kelompok, karena adanya pengaruh hingga peniruan kelompok yang membuat anggota komunitas dapat merubah identitas diri mereka.

Fenomena pembentukan identitas remaja yang bergabung dalam komunitas ini menarik untuk diteliti terutama komunitas K-Pop dance cover, karena pada umumnya komunitas sebagai wadah berkumpulnya orang-orang yang memiliki tujuan yang sama. Di dalam komunitas dance cover yang dimana mereka memiliki anggota remaja ini, ketika masuk 
ke dalam komunitas mereka melalukan pertukaran symbol dan memberikan makna sehingga menjadi satu dalam komunitas dan membentuk identitas yang sama. Oleh karena itu, peneliti ingin melihat pembentukan identitas yang terjadi pada anggota komunitas dance cover Light Galaxy.

\section{Tujuan Penelitian}

Tujuan penelitian ini adalah untuk mengetahui bagaimana proses pembentukan identitas diri pada komunitas cover dance kpop Light Galaxy di Semarang.

\section{Kerangka Teori}

\subsection{Identitas Diri}

Sunaryo (2004:36) menyatakan bahwa identitas diri merupakan kesadaran akan diri sendiri yang berasal dari pengamatan dan penilaian orang lain, sebagai campuran dari semua aspek konsep diri dan menjadi satu kesatuan yang utuh. Ini berarti untuk mengetahui identitas diri masingmasing mereka harus sadar akan diri pribadinya sendiri terlebih dahulu, untuk mengetahui diri pribadinya dibutuhkan pengamatan dari orang lain atau penilaian dari orang lain. Pengamatan dan penilaian dari setiap orang lain pasti akan berbeda karena mereka memiliki sudut pandang sendiri-sendiri. Dengan perbedaan itu bias dijadikan satu yang sama dan dapat disimpulkan identitas diri apa yang dimiliki.

Terdapatteorikomunikasitentang identitasmenurut Michael Hecht (Littlejohn,2009:131) yang meliputi 3 konteks budaya yaitu individu, komunal dan publik. Menurut teori tersebut, identitas menjadi penghubung yang utama antara individu dengan masyarakat serta komunikasi menjadi mata rantai yang memperbolehkan hubungan itu terjadi. Selain konteks budaya, Hecht sekaligus memperkenalkan dimensi-dimensi identitas secara khusus, dimana terdapat dimensi afektif (perasaan), dimensi kognitif (pemikiran), dimensi perilaku (tindakan), dan dimensi spiritual (transenden). Karena memiliki jangkuan yang luar biasa, identitas merupakan sumber bagi motivasi dan ekspetasi dalam kehidupan serta memiliki kekuatan yang tetap, namun identitas dapat dibentuk ketika seseorang berinteraksi secara sosial dengan orang lain di dalam kehidupan nya.

\subsection{Simbolis Interaksionisme}

Manusia pada hakikatnya merupakan makhluk dimana berinteraksi dengan seseorang merupakan kegiatan yang dilakukan sehari-hari. Dalam berinteraksi tentunya memerlukan sarana tertentu. Sarana dapat menjadi medium simbolisasi dari apa yang dimaksudkan dalam sebuah interaksi. Simbolis Interaksionisme sendiri memiliki sejumlah asumsi pokok yaitu :

a) Konsep diri tidak langsung ditentukan saat individu lahir, karena konsep diri akan terbentuk dan berkembang melalui komunikasi dan interaksi sosial yang dilakukan

b) Konsep diri dapat terbentuk ketika individu melakukan reaksi terhadap orang lain dan 
melalui persepsi atas perilaku yang dilakukan.

c) Setelah konsep diri berubah, hal tersebut akan menjadi dasar dari tingkah laku individuh

d) Manusia dipandang menjadi mahkluk yang unik karena dapat menggunakan dan mengembangkan symbol untuk keperluan hidupnya.j

e) Manusia dapat bereaksi dan mendefinisikan sesuatu.

f) Makna merupakan kesepakatan bersama lingkungan sosial sebagai hasil interaksi. (Mufid,2009:150-151)

Selain asumsi pokok, simbolis interaksionisme juga mempunyai istilah pokok yaitu:

a) Identities (identitas) adalah makna diri dalam mengambil peran hidup.

b) Language (bahasa), adalah symbol yang digunakan atau hanya diketahui oleh anggota kelompok itu sendiri. Bahasa ini digunakan sebagai alat komunikasi pada komunitas atau kelompok.

c) Looking glass self (cara melihat diri), adalah gambaran mental sebagai hasil dari mengambil peran dari orang lain, yang dimaksud disini merupakan kita harus bisa memposisikan diri kita dengan posisi orang yang berinteraksi dengan kita, agar dapat memperoleh gambaran apa yang orang lain lihat tentang diri kita.

d) Meaning (makna) adalah tujuan dan atribut bagi sesuatu, makna ditentukan oleh bagaimana kita merespon dan menggunakannya

e) Mind (pikiran) proses mental yang terdiri dari self, interaksi, dan refleksi. Ini berdasarkan interaksi sosial yang didapat

f) Role taking (bermain peran) adalah kemampuan yang dapat melihat diri seorang sebagai objek, sehingga dapat memperoleh gambaran bagaimana dia melihat orang lain tersebut

g) Self-concept (konsep diri), adalah gambaran tentang siapa dan bagaimana diri kita sejak kecil melalui interaksi dengan orang lain. Konsep diri dapat berubah sewaktu-waktu

h) Self-fulling prophecy (harapan untuk pemenuhan diri), yakni tendensi ekspentasi untuk memunculkan respon bagi orang lain yang diantisipasi oleh kita.

(Mufid,2009:158-160)

Mead mempunyai pemikiran yang luar biasa tentang interaksionisme, pemikiran Mead dapat terangkum dalam konsep pokok mengenai "mind", "self", dan "society".

a. Konsep Mead tentang "Mind"

Definisi "mind" menurut Mead sendiri adalah sebagai sebuah fenomena sosial yang dapat tumbuh dan berkembang di dalam proses sosial yang dapat dijadikan sebagai hasil dari interaksi. Dalam hal ini mind mirip dengan sebuah symbol, yang merupakan sebagai hasi dari interaksi sosial. Hanya saja, mind terbentuk setelah terjadinya percakapan diri (selfconversation), yang artinya ketika seseoarang melakukan interaksi, hal tersebut sama saja dengan berpikir. 


\section{b. Konsep Mead tentang "Self"}

Konsep dari self menurut Mead merupakan sebuah proses yang dapat tumbuh di keseharian sosial dimana dapat membentuk identitas diri. Self memiliki dua segi, yaitu "I" dan "Me". Dua segi dari self memiliki arti masing-masing yaitu "I" sebagai "aku" yang dimana sebagai diri sendiri yang tidak terorganisasi dan tak dapat ditebak oleh orang lain, sekaligus menjadi rumusan subjektif tentang diri ketika berinterkasi dengan orang lain. Sedangkan "Me" sebagai "daku" diamana terdapat perilaku sosial yang diterima dan diadaptasi melalui tindakan dari orang lain.

c. Konsep Mead "Society"

Menurut Mead society adalah kumpulan dari self yang melakukan interaksi dengan lingkungan disekitarnya yang berupa hubungan dari personal, kelompok hingga komunitas yang dijalani nya.

\subsection{Komunitas dan Komunikasi Kelompok}

Komunitas berasal dari bahasa Latincommunitas yang berarti "kesamaan", kemudian dapat diturunkan dari communis yang berarti "sama, publik, dibagi oleh semua atau banyak". Sehingga pengertian komunitas adalah sekelompok orang yang saling berbagi lingkungan, perhatian, masalah, serta memiliki ketertarikan atau kegemaran yang sama terhadap suatu topik, dan dapat memperdalam pengetahuan serta keahliannya dengan saling berinteraksi secara terus menerus (Wenger, 2002: 4).

Michael Burgoon dan Michael Ruffner memberikan batasan komunikasi kelompok sebagai interaksi tatap muka dari tiga atau lebih individu guna memperoleh maksud atau tujuan yang dikehendaki, seperti berbagai informasi, pemeliharaan diri, atau pemecahan masalah sehingga semua anggota dapat menumbuhkan karakteristik pribadi anggota lainnya dengan akurat (Mufid,2009:156).

\section{Metode Penelitian}

Penelitian ini menggunakan metode kualitatif dengan pendekatan fenomenologi. Penelitian kualitatif dapat menciptakan data deskriptif yang berbentuk kalimat tertulis maupun lisan yang diperoleh dari wawancara dan mengamati perilaku seseorang (Moleong, 2007: 4). Pendekatan yang dilakukan ini ditujukan melalui latar dari individu tersebut secara keseluruhan.. Fenomenologi merupakan cara yang digunakan manusia untuk memahami dunia melalui pengalaman langsung. Semua pengetahuian akan dunia, bahkan pengetahuan ilmiah diperoleh dari beberapa pengalaman akan dunia. Dengan demikian fenomenologi membuat pengalaman nyata sebagai data pokok sebuah realitas. Semua yang dapat anda ketahui adalah apa yang anda alami. Fenomenologi berarti membiarkan segala sesuatu menjadi jelas sebagaimana adanya (Little john,2014:57). 
Objek dalam penelitian ini adalah komunitas dance cover Light Galaxy, dan mengambil data dengan wawancara mendalam dengan para anggota komunitas Light Galaxy. Serta melakukan triangulasi data dengan mewawancarai sahabat dari anggota komunitas Light Galaxy sehingga dapat mengetahui pembentukan identitas diri yang terjadi pada anggota.

\section{Hasil Penelitian}

Pada bab ini, peneliti akan menguraikan tentang hasil dan pembahasan dari penelitian mengenai pembentukan identitas yang terjadi pada anggota komunitas Light Galaxy. Hasil penelitian ini memperoleh terdapat pembentukan identitas yang terjadi dimana para narasumber terdapat perubahan yang terjadi dalam diri mereka.

\subsection{Pembentukan Identitas "I"}

Pembentukan identitas "I" dialami oleh seluruh narasumber. Terdapat beberapa hal yang menyebabkan narasumber membentuk identitas "I", dimulai dengan alasan dari narasumber mengapa menyukai K-pop. Pada pembentukan identitas ini semua narasumber memiliki perbedaan alasan awal mereka mengapa menyukai K-Pop, dimana narasumbe 1 menyukai K-Pop karena melihat visual tampan dari boyband nya, selanjutnya narasumber 2 menyukai K-Pop karena game yang dimilikinya terdapat lagu K-Pop, kemudian narasumber 3 yang menyukai K-Pop berawal dari menonton drama Korea. Akan tetapi, terdapat kesamaan di narasumber 2 dan 3 dimana mereka menyukai music K-Pop karena disetiap music nya terdapat feel tersendiri, dan bagi narasumber 1 semakin K-Pop karena adanya konsep-konsep unik yang dimiliki boyband dan girlband Korea.

Setelah itu, menyukai K-Pop memberikan dampak perubahan bagi narasumber. Semua narasumber mengakui terdapat perubahan dalam diri mereka setelah menyukai K-Pop. Namun terdapat perbedaan perubahan di setiap narasumber, seperti narasumber 3 yang menyatakan bahwa sejak menyukai K-Pop dirinya menyukai dance, narasumber 1 juga menyatakan bahwa semnejak menyukai kpop memiliki kepribadian yang pendiam dan selalu membahas k-pop jika bersama teman-teman. Selain perbedaan terdapat juga persama di semua narasumber yaitu dalam hal konsumsi, dimana mereka semua mengubah selera musik nya menjadi k-pop hingga menonton konser nya. Dan juga ruang lingkup pertemanan narasumber 2 dan 3 pun juga berubah. Seperti pada gambar dibawah membuktikan bahwa semenjak menjadi k-popers mereka sering menonton konser dan memiliki pertemanan yang sama-sama menyukai k-pop juga. 


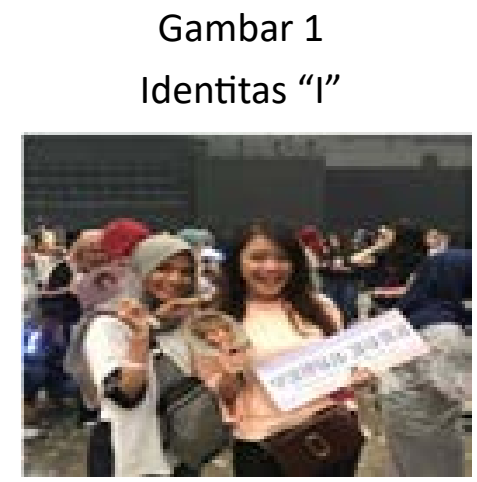

Sumber: dokumen peneliti

Alasan menyukai hingga terjadinya perubahan pada diri narasamuber, merupakan proses pembentukan identitas "I" dimana identitas yang mereka miliki, merupakan identitas sebagai perilaku penggemar K-Pop. Pembentukan identitas "l" pada narasumber terdapat perbedaan, namun terdapat juga persamaan yang dialami setiap narasumber. Persamaanpersamaan ini lah yang menentukan identitas "I" narasumber merupakan sebagai penggemar K-Pop.

\subsection{Pembentukan Identitas Kelompok "Me"}

Semua narasumber bergabung di komunitas Light Galaxy yang merupakan komunitas dance cover K-Pop, yang tentunya di dalam komunitas memiliki berbagai kegiatan. Kegiatan-kegiatan yang dilakukan narasumber berupa latihan dimana narasumber 1 dan 2 menyatakan bahwa latihan yang sering dilakukan di komunitas, selain itu terdapat kegiatan project dan kreativitas dimana mereka mengikuti event-event lomba dance cover K-Pop sekaligus menghiasi kostum agar terlihat unik. Tak hanya itu, project yang mereka lakukan juga project untuk membuat video tentang dance cover juga tentunya. Narasumber 2 dan 3 juga mengungkapkan bahwa adanya kegiatan liburan atau bermain bersama-sama dengan anggota komunitas, yang dimana mempunyai tujuan untuk mengakrabkan diri dengan sesama anggota komunitas.

\section{Gambar 2}

Identitas Kelompok "Me"

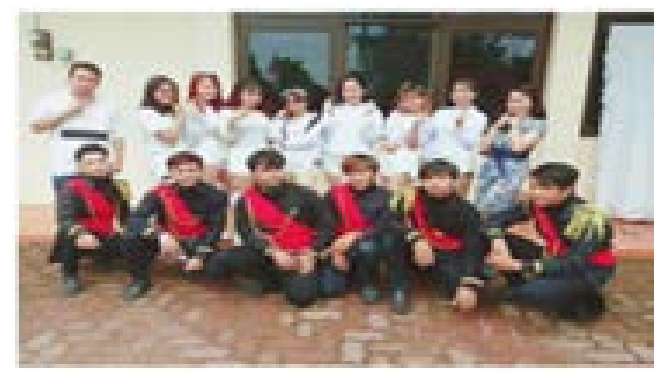

Sumber: dokumen peneliti 
Selanjutnya dapat dilihat melalui gambar, karena komunitas ini merupakan komunitas dance cover yang dimana setiap narasumber diharuskan meniru idol yang mereka cover, dimulai dari ekpresi hingga penampilan yang mereka miliki harus mereka ubah agar sama dengan idol yang mereka cover, sehingga setiap narasumber mengalami perubahan pada diri mereka karena menirukan idol yang mereka cover saat di panggung.

Semua narasumber menyatakan bahwa selama berada di komunitas mereka mendapatkan pengaruh-pengaruh dari komunitas. Pengaruh-pengaruh yang di alami oleh narasumber berupa hal keuangan, waktu hingga karakternya. Pengaruh yang diberikan dapat di komunitas menyebabkan semua narasumber mengubah diri mereka menjadi lebih baik. Dimana perubahan yang di alami oleh setiap narasumber meliputi dapat perubahan style yang dimana mereka lebih style Korea, menggunakan bahasa-bahasa umum Korea, menjadi diri yang terbuka dengan orang lain dan juga menjadi lebih percaya diri.

Kegiatan hingga perubahan yang di alami oleh setiap narasumber menyebabkan terjadinya pembentukan identitas "Me" di dalam diri setiap narasumber, dikarenakan setiap kegiatan yang dilakukan terjalin interaksi satu sama lain sehingga setiap narasumber terpengaruh dan mengubah diri mereka sesuai dengan ketentuan kelompoknya.

\subsection{Pergeseran Identitas "I" dan "Me"}

Pergeseran Identitas "I" dan "Me" dapat terjadi di setiap narasumber, karena setiap narasumber membentuk identitas "I" dan "Me". Pergeseran yang terjadi pada setiap narasumber dimulai dengan adanya peniruan kelompok yang dilakukan tiap narasumber. Peniruan yang dilakukan di komunitas pun beragam, mulai dari peniruan perilaku, style, bahasa hingga penampilan. Dan ketika berada di luar komunitas semua narasumber menyatakan bahwa terdapat perbedaan diri mereka pada saat berada di luar komunitas, perbedaan yang terjadi pada saat berada di luar komunitas meliputi bahasa dan peilaku.

$\mathrm{Hal}$ ini yang menyebabkan adanya pergeseran antara identitas "I" dan "Me" dimana saat berada di komunitas mereka melakukan hal yang sama dengan anggota komunitas yang lain nya, "ya gimana ya soalnya tiap kumpul gitu jadi ya jadi kebiasaan gitu. Kalo tepat waktu dan tanggung jawab kan karna emang kita setim kan pastinya harus ada tanggung jawab yang dimiliki semacam penyesuain diri" ujar narasumber 1. Dimana narasumber 1 menjelaskan bahwa narasumber sering berkumpul dengan anggota sehingga menjadi kebiasaan dan menyesuaikan dengan anggota komunitasnya. Hal ini menyebabkan semua narasumber menampakan identitas kelompok "Me" pada saat berkumpul di komunitas. Namun ketika berada di luar komunitas, semua narasumber berubah menjadi identitas "I" dimana menjadi diri mereka sendiri pada saat di luar komunitas.

\subsection{Esensi Perubahan Identitas Diri}

Berdasarkan penjabaran diatas, penulis menemukan bahwa setiap narasumber mengalami pembentukan identitas pada diri mereka. Hal ini terjadi karena adanya identitas "I" dan 
pembentukan identitas "Me" yang terjadi pada narasumber. Pembentukan identitas yang dialami oleh narasumber disebabkan karena adanya proses interaksionisme simbolik yang mempunyai definisi sebagai "cara kita menginterprestasikan dan memberi makna pada lingkungan di sekitar kita melalui cara kita berinteraksi dengan orang lain". Pemikiran Mead tentang interaksionisme simbolik terangkum dalam konsep pokok mengenai "mind", "self", dan "society". (Mufid,2009:149-160). Sehingga berdasarkan teori setiap narasumber menginterprestasikan dan memberikan makna di lingkungan komunitas melalui cara mereka berinteraksi dengan anggota komunitasnya.

Gambar 3. Interaksionisme Simbolik

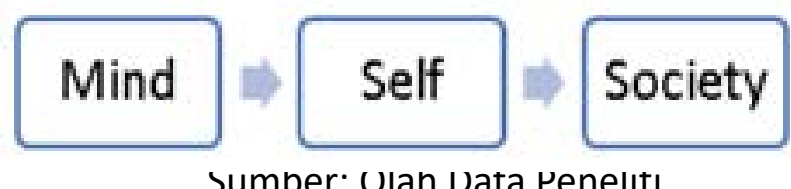

Hal pertama dalam pembetukan identitas adalah mind. Dimana Mead (Mufid,2009:163) mendefinisikan "mind" sebagai fenomena sosial yang tumbuh dan berkembang dalam proses sosial sebagai hasil dari interaksi. Mind terbentuk setelah terjadinya percakapan diri. Disini sebagai anggota komunitas, narasumber melakukan komunikasi atau percakapan dengan sesama anggota komunitas Light Galaxy, dengan merespon percakapan yang dilakukan, narasumber sudah melakukan proses mind yang dimana mereka melakukan interaksi dengan sesama anggota komunitas Light Galaxy.

Selanjutnya terdapat self yang menurut Mead merupakan proses yang tumbuh dalam keseharian sosial yang membentuk identitas diri. Self sendiri dibagi menjadi dua segi yaitu "I" dan "Me". Identitas "I" merupakan sebagai "aku" yang dimana mempunyai bagian yang unik, impulsive, spontan, tidak terorganisasi, tidak bertujuan, dan tidak dapat diramal oleh orang lain (Mufid,2009:164). Berdasarkan analisa tema struktural yang menyebutkan bahwa identitas "I" dimulai dengan adanya alasan narasumber menyukai K-Pop dan terjadinya perubahan narasumber setelah menyukai K-Pop. Hal ini tentunya terdapat perbedaan dan persamaan di setiap narasumber. Perubahan-perubahan yang terjadi di narasumber dapat disumpulkan bahwa identitas "I" yang dimiliki oleh semua narasumber adalah sebagai penggemar K-Pop. Menjadi penggemar K-Pop sama halnya masuk ke dalam sebuah fandom, dimana Indrayani (2016:47) menyatakan bahwa fandom merupakan penggemar yang memiliki kegilaan terhadap segala sesuatu yang berkaitan dengan badminton dan menunjukkan pengalamannya menjadi fans secara kontinu kemudian menghadirkan kembali pengalaman emosional secara konsisten. Bentuk pengalaman yang dimiliki fans adalah sebagai konsumen olahraga yang mengonsumsi secara langsung di stadion, arena atau lapangan, ataupun tidak langsung yaitu melalui televisi, radio, majalah, media online dan berdiskusi dalam berbagai situasi secara terus-menerus. 
Peristiwa ini sama dengan penggemar K-Pop dimana mereka memiliki kegilaan terhadap sesuatu yang berkaitan dengan K-Pop hingga ingin mengikuti idol yang dilakukannya yaitu dance hingga style yang dimiliki idolnya, hal ini dinyatakan oleh narasumber 2. Dan juga, bentuk pengalaman fans sebagai konsumen dengan menonton secara langsung juga dilakukan oleh narasumber 3, dan secara tidak langsung dilakukan oleh narasumber 1 dan 2 . Sehingga dalam hal ini pengalaman narasumber yang didapat sebagai penggemar K-Pop adalah mendapatkan identitas "I" dan juga pengalaman sebagai fandom.

Setiap narasumber setelah bergabung dengan komunitas Light Galaxy mengalami pembentukan Identitas "Me" atau bisa disebut dengan "daku" yang merupakan dari unsur generalized other, dimana sebagai fungsi bimbingan dan panduan. Identitas "Me" merupakan perilaku individu yang secara sosial diterima dan diadaptasi oleh individu. (Mufid,2009:164). Hal ini dialami oleh semua narasumber, dimana narasumber menerima dan mengadaptasi peran orang lain melalui proses interanalisasi. Proses internalisasi menurut Kalid Jernih (2010:71) dimana internalisasi merupakan proses individu belajar dan diterima menjadi bagian sosial dan sekaligus mengikat diri ke dalam nilai dan norma sosial dan perilaku suatu masyarakat. Berdasarkan penjelasan di analisa gabungan struktural terdapat pengaruh-pengaruh yang didapatkan di komunitas hal ini karena adanya ketentuan-ketentuan yang diadakan di komunitas, semua narasumber mengungkapkan bahwa adanya ketentuan-ketentuan dalam hal keuangan hingga waktu. Ketentuan ini lah yang menyebabkan narasumber mengikat diri dengan ketentuan yang diberikan oleh komunitas sehingga narasumber dapat menjadi bagian dari komunitas sekaligus narasumber merasakan dimensi kognitif yang dimana dengan adanya ketentuan tersebut menambahkan pengetahuan dan pemahaman akan komunitas. Ketika narasumber bergabung di komunitas, mereka merasakan perubahan dalam dirinya ketika menjadi bagian dari komunitas, perubahan yang di dirasakan setiap narasumber pun berbeda-beda. Tidak hanya narasumber saja yang mendapati dirinya berubah, namun orang lain juga $\mathrm{Hal}$ ini diungkap oleh sahabat narasumber dimana narasumber 4 menyatakan bahwa semenjak bergabung dengan komunitas, narasumber 1 mulai mengerti dengan kosmetik, karena sebelumnya narasumber 1 tidak sama sekali menggunakan kosmetik, tidak hanya disitu saja, menurut narasumber 4 semenjak narasumber 1 menjadi anggota komunitas Light Galaxy, narasumber 1 mulai mendapatkan prestasi-prestasi nya. Hal ini juga dinyatakan oleh narasumber 5 dimana narasumber 2 setelah bergabung dengan komunitas, mendapatkan banyak prestasi yang dimiliki. Dengan pernyataan sahabat narasumber membuktikan bahwa benar adanya narasumber beradaptasi dan dapat menjadi bagian komunitas karena mendapatkan pengaruh dari komunitas sehingga mengubah kebiasaan yang dimilikinya, hal ini termasuk juga di dalam bagian demensi perilaku yang dimana terdapat perubahan tindakan yang dimiliki setelah bergabung dengan komunitas. 
Pembentukan identitas "Me" tentunya tidak disini saja, terdapat konsep role taking dimana konsep ini sangat penting. Dimana sebelum seseorang bertindak, ia membayangkan dirinya dalam posisi orang lain sehingga mencoba untuk memahami apa yang diharapkan orang tersebut. Hanya dengan mencocokan diri dengan orang lain, maka interaksi menjadi mungkin. Semakin mampu seseorang mengambil alih peran sosial, semakin terbentuk identitas dirinya (Mufid,2009;161). Hal ini sama seperti yang diungkapkan oleh setiap narasumber dimana mereka meniru dimulai dari bahasa hingga perilaku anggota komunitas sehingga selaras dengan anggota komunitasnya. Peniruan yang dilakukan narasumber termasuk di dalam dimensi spiritual yang merupakan timbul rasa percaya akan komunitasnya sehingga mereka melakukan peniruan, namun tidak hanya menirukan saja, mereka juga menyesuaikan diri dengan anggota-anggota komunitas sehingga menjadikan nya kebiasaan. Peniruan ini dilakukan narasumber karena adanya penyesuaian narasumber sebagai anggota komunitas atau bisa disebut dengan self indication. Dimana menurut blumer merupakan peristiwa yang terjadi pada saat individu berada di dalam kelompok dan individu mengantisipasi tindakantindakan orang lain dan menyesuaikan tindakannya sebagaimana dia memaknakan tindakannya (Mufid,2009;149). Peniruan bahasa yang dilakukan narasumber 1 dan 3 merupakan salah satu pokok dari teori interaksionisme simbolik dimana bahasa menjadikan suatu symbol yang digunakan bersama diantara anggota kelompok sosial dan bahasa ini digunakan sebagai alat komunikasi (Mufid,2009;158). Sehingga penggunaa symbol korea hingga bahasa korea umum, membuktikan sudah terjadinya pertukaran makna pada narasumber. Peniruanpeniruan yang dilakukan oleh narasumber dapat mengubah diri mereka, hal ini didukung oleh sahabat narasumber dimana narasumber 5 dan 6 menyatakan bahwa sahabat mereka yaitu narasumber 2 dan 3 mengalami perubahan ketika sudah di komunitas. Perubahan yang dialami oleh narasumber 1 dan 3 meliputi perilaku hingga stylenya dimana narasumber 2 dan 3 menjadi orang yang memiliki percaya diri dan memiliki style ala Korea. Seperti gambar di bawah dapat dilihat bahwa narasumber 3 meniru style ala Korea dengan mengecat warna rambut dan menggunakan baju-baju ala Korea.

Gambar 4

Internalisasi Identitas

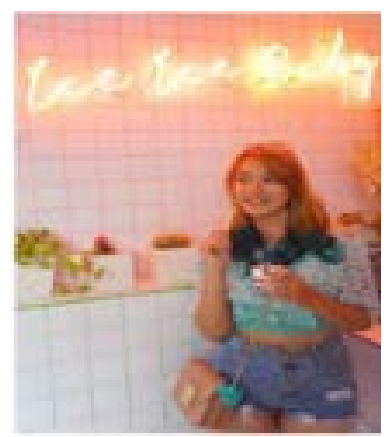

Sumber: dokumen peneliti 
Sama seperti narasumber 2 dan 3 ,namun narasumber 4 menyatakan bahwa selain perilaku dan style yang berubah, bahasa yang digunakan pun juga ikut berubah yaitu dapat mengerti bahasa Korea. Peniruan ini lah yang membentuk identitas kelompok (Me) dimana mereka terdapat beberapa perubahan dalam style, kepribadian, perilaku dan bahasa. Namun narasumber menunjukan keseluruhan identitas kelompok "Me" ketika berkumpul pada saat di komunitas dan menunjukan beberapa identitas "Me" ketika berada di luar komunitas. Hal ini terjadi karena adanya rasa nyaman dan keterikatan dengan komunitas atau bida disebut dengan dimensi afektif sehingga ketika berada di dalam komunitas mereka akan menunjukan identitas "Me" mereka secara keseluruhan. Karena terdapat perubahan ketika mereka berada di luar kelompok semua narsumber menyatakan bahwa bahasa hingga perilaku mereka di dalam komunitas dan di luar komunitas berbeda. Sehingga hal ini menyebabkan adanya perubahan identitas "I" dan "Me" secara dinamis di setiap interaksi yang dilakukan oleh narasumber.

Yang terkahir terdapat society dimana mempunyai arti sebagai kumpulan self yang melakukan interaksi dalam lingkungan yang lebih luas (Mufid,2009:165). Hal ini dilakukan oleh narasumber dimana ketika narasumber memiliki identitas baru yang melakukan interaksi tidak hanya di komunitas Light Galaxy, namun juga terdapat di hubungan personal seperti teman dan keluarga sehingga orang lain dapat melihat identitas baru narasumber yang dimana sahabatnya mengaku narasumber terdapat beberapa perubahan setelah menjadi bagian di dalam komunitas yaitu lebih percaya diri, fashionable dan tentunya lebih terbuka dengan orang lain.

\section{Simpulan}

Dari hasil penelitian yang telah dilakukan, dapat diambil kesimpulan bahwa terjadi pembentukan identitas diri yang dimiliki oleh anggota komunitas Light Galaxy yang terjadi diawali dengan adanya proses mind, self dan society. Dimana proses mind dalam narasumber adalah karena adanya respon dalam berkomunikasi dengan sesama anggota sehingga terjadi lah interaksi yang dilakukan oleh sesama anggota komunitas Light Galaxy, karena adanya respon dalam berkomunikasi dengan sesama anggota komunitas sehingga narasumber yang sebelumnya tidak mengetahui tentang bahasa Korea, style Korea, hingga dance cover, karena adanya proses mind ini narasumber menjadi tau akan tentang Korea hinga dance cover. Selanjutnya self yang merupakan keseharian mereka di dalam komunitas Light Galaxy dan menyebabkan pembentukan identitas diri. Dalam proses self ini mengacu pada pembentukan identitas yang dimiliki narasumber, hasil penelitian menunjukan pembentukan identitas diri pada anggota komunitas Light Galaxy melalui beberapa proses dalam segi Self, yaitu:

1. Identitas "I" dimana identitas ini dapat terbentuk karena adanya pengaruh dari menyukai K-Pop, dengan menyukai K-Pop narasumber mendapatkan pengaruh-pengaruh dari K-Pop. Sehingga mereka menjadi penggemar K-Pop sekaligus menjadi bagian fandom 
K-Pop.

2. Pembentukan identitas "Me" terjadi ketika memasuki komunitas dimana mereka mengikuti ketentuan yang ada di komunitas dan melakukan interaksi dengan orang lain. Adanya pembentukan identitas "Me" karena adanya penyesuaian diri yang dilakukan oleh narasumber sehingga narasumber beradaptasi sekaligus mengampil peran orang lain. Dimana identitas "Me" di narasumber menjadi anggota komunitas dance cover. Tak luput dari seorang fandom dimana mereka ingin menirukan idol yang disukainya

3. Pergeseran identitas " $I$ " dan "Me" terjadi ketika narasumber merubah diri nya ketika di dalam komunitas dan diluar komunitas. Hal ini terjadi karena adanya interaksi sosial yang dilakukan. Dimana ketika di luar komunitas, mereka tidak menggunakan bahasa Korea. Identitas Me yang dimiliki anggota akan ditunjukan selama di komunitas saja dan hanya sebagian identitas Me yang akan ditunjukan di luar komunitas.

Proses terakhir dalam pembentukan identitas diri yaitu society, yaitu merupakan identitas baru yang dimiliki oleh narasumber dan melakukan interaksi di lingkungan sekitarnya, identitas baru yang dimiliki narasumber pun diakui juga oleh sahabat mereka dimana berdasarkan pengamatan sahabatnya narasumber mengalami perubahan lebih terbuka, fashionable hingga percaya diri. Pembentukan identitas di dalam narasumber ini cenderung menerima dampak yang lebih positif yang dimana mereka lebih percaya diri, fashionable dan lebih terbuka. Namun juga terdapat sisi negative dimana mereka lebih memakai style fashion ala Korea yang gaya busana nya lebih terbuka.

\section{Daftar Pustaka}

Santrock, John W. (2003). Adolescence Perkembangan Remaja: Jakarta: Erlangga Mufid, Muhamad.(2009) Etika dan Filsafat Komunikasi. Jakarta:Prenadamedia Group Moleong, Lexy J. (2007). Metodologi Penelitian Kualitatif. Bandung: PT Remaja Rosdakarya Rakhmat, Jalaluddin. (2011). PsikologiKomunikasi. Bandung: PT. Remaja Rosdakarya.

Visit Korea Year: The 2012 K-Pop Cover Dance Held to Celebrate Visit Korea Year. (2012). Dalam http://english.visitkoreayear.com/english/community/community_01_01_01_ view. asp?bidx=292\&st=\&sech=\&page=1. Diunduh 3 Maret 2019

Sunaryo. 2004. Psikologi Untuk Pendidikan. Jakarta: EGC.

Littlejohn, Stephen W \& Karen A. Foss.(2009). Teori Komunikasi, edisi 9. Jakarta: Salemba Humanika

Indrayani, Heni.(2016). Fandom: Strategi Komunikasi Pemasaran 3.0 untuk Melanggengkan Fantasi Nasionalisme Melalui Olahraga. Thesis. Universitas Dipenogoro

Wahyudi A.M. (2013). Mehamami Fenomena Hallyu (Gelombang Korea). Jurnal Masyarakat dan Budaya..

Alasan Remaja Rentan Terpengaruh Dampak Buruk Lingkungan. (2014). Dalam https://www. beritasatu.com/gaya-hidup/173183/alasan-remaja-rentan-terpengaru\%20h-dampakburuk-lingkungan. Diunduh 7 Mei 2019 